\title{
Hubungan Sindrom Pramenstruasi dengan Aktivitas Belajar Siswi SMAN 1 Payakumbuh
}

\author{
Ryri Rahmawati Helmi ${ }^{1}$, Yaslinda Yaunin ${ }^{2}$, Almurdi $^{3}$
}

\section{Abstrak}

Sindrom pramenstruasi merupakan suatu penampilan siklik dari satu atau lebih gejala yang terjadi sebelum menstruasi yang mempengaruhi aktivitas seorang wanita. Tujuan penelitian ini adalah untuk menganalisis hubungan sindrom pramenstruasi dengan aktivitas belajar siswi SMAN 1 Payakumbuh. Penelitian ini merupakan survai analitik dengan desain cross sectional study. Sampel dalam penelitian ini berjumlah 153 orang siswi. Hasil penelitian didapatkan: 1) Responden yang mengalami sindrom pramenstruasi yaitu sebanyak 150 orang (98\%); 2) 130 orang $(84,9 \%)$ responden mengalami gejala fisik dan psikis sindrom pramenstruasi; 3) Sebanyak 108 orang (72\%) mengalami gangguan belajar yang ringan yaitu masih dapat mengikuti aktivitas belajar di sekolah atau di tempat kursus tapi tidak mampu berkonsentrasi dengan baik.; 4) hasil uji statistik menggunakan chi-square untuk melihat hubungan antara gejala sindrom pramenstruasi dengan derajat gangguan aktivitas belajar diperoleh nilai $p=0,022$ $(p<0,05)$. Sebagian besar siswi SMA mengalami sindrom pramenstruasi. Sindrom pramenstruasi yang diderita oleh siswi SMA menyebabkan gangguan belajar yang ringan yaitu masih dapat mengikuti aktivitas belajar di sekolah atau di tempat kursus tapi tidak mampu berkonsentrasi dengan baik. Berdasarkan uji statistik dapat disimpulkan bahwa terdapat hubungan yang bermakna antara gejala sindrom pramenstruasi dengan derajat gangguan aktivitas belajar.

Kata kunci: sindrom pramenstruasi, aktivitas belajar, gangguan belajar ringan

\begin{abstract}
Premenstrual syndrome is a cyclic appearance of one or more symptoms that occur before menstruation that affect the activity of a woman. The objective of this study was to analyze the relationship of premenstrual syndrome on learning activities of the students in SMAN 1 Payakumbuh. This study was a survey of a cross sectional analytic study. The sample in this research were 153 people schoolgirls. The results from this study were: 1) Respondents who experience premenstrual syndrome were 150 people (98\%); 2)130 respondents (84,9\%) had physical and psychological symptoms; 3) 108 people (72\%) sufferred mild learning disabilities that were still able to attend school activities or on the course but was not able to concentrate well. 4) the result of chi square statistical test pshowed that the were relationship between symptoms of premenstrual syndrom with the degrees of learning activities disturbances is $p$ value $=0,022, p<0,05$. Most of the girls suffered premenstrual syndrome. The premenstrual syndrom that occured cause mild learning disabilities that are still able to attend school activities or on the course but was not able to concentrate well. Based on statistical test result, it can be concluded that there is a significant relationship between the symptoms of premenstrual syndrome with learning activities disturbances.
\end{abstract}

Keywords:premenstrual syndrome, learning activities, mild learning disorders

Affiliasi penulis: 1. Prodi Profesi Dokter FK Unand (Fakultas Kedokteran Universitas Andalas Padang), 2. Bagian Psikiatri FK Unand, 3. Bagian Patologi Klinik FK Unand

Korespondensi: Ryri Rahmawati Helmi, email:

iemawa_91@yahoo.com, Telp: 081261361915

\section{PENDAHULUAN}

Aktivitas belajar adalah keseluruhan aktivitas siswa dalam proses belajar mengajar yang terdiri dari kegiatan fisik dan psikis. Seorang siswa agar dapat 
menjalankan kegiatan belajar dengan baik tentunya kondisi fisik dan psikis mereka juga harus dalam keadaan optimal. Kondisi fisik harus bebas dari penyakit sedangkan kondisi psikis terlepas dari gangguan kejiwaan dan ketegangan emosional. ${ }^{1}$

Sindrom pramenstruasi atau yang lebih sering dikenal dengan istilah Premenstrual Syndrome (PMS) adalah gejala perubahan fisik dan perilaku yang muncul pada separuh akhir dari siklus menstruasi dan hilang saat mulainya menstruasi. ${ }^{2}$ Gejala ini tepatnya muncul segera setelah ovulasi, meningkat secara bertahap dan mencapai puncaknya lima hari sebelum periode menstruasi dimulai. ${ }^{3}$ Keluhan atau gejala yang sering ditemukan pada sindrom pramenstruasi terdiri atas gejala fisik seperti nyeri kepala, nyeri payudara, edema pada tungkai, dan gejala psikis seperti mudah menangis, suasana hati tidak nyaman, kelelahan, kurang percaya diri, gugup, bingung, mudah tersinggung, insomnia, gelisah, marah tidak beralasan, sulit berkonsentrasi dan kecemasan. ${ }^{4}$ Penyebab pasti sindrom pramenstruasi belum diketahui, namun karena sindrom ini terjadi didalam siklus haid yang normal, maka hormon-hormon yang berperan dalam terjadinya menstruasi diduga sebagai penyebab terjadinya hal ini. ${ }^{5}$ Perubahan rasio antara esterogen dan progesteron selama siklus menstruasi adalah salah satu penyebabnya. ${ }^{4}$ Sekitar sepertiga wanita yang dalam usia reproduktif mengalami sindrom pramenstruasi. ${ }^{2}$ Sebanyak 14 sampai $98 \%$ remaja putri memiliki gejala sindrom pramenstruasi yang bervariasi dari sedang hingga berat. ${ }^{5}$ Penelitian yang dilakukan terhadap 384 remaja putri yang berusia 15 tahun, didapatkan jumlah remaja tersebut yang mengalami sindrom pramenstruasi sebanyak $14 \%{ }^{6}$ Hasil penelitian lainnya tentang sindrom pramenstruasi yang dilakukan terhadap mahasiswi Fakultas Kedokteran Universitas Andalas angkatan 2000/2001, didapatkan bahwa $80,89 \%$ sampel penelitian menderita sindrom ini dan $61,6 \%$ diantaranya mengalami gangguan belajar. ${ }^{7}$ Berdasarkan data tersebut maka dilakukan penelitian untuk mengetahui hubungan sindrom pramenstruasi dengan aktivitas belajar pada siswi SMAN 1 Payakumbuh.

\section{METODE}

Penelitian dilakukan di SMAN 1 Payakumbuh pada bulan Juni 2012. Subjek penelitian adalah seluruh siswi SMAN 1 Payakumbuh dengan jumlah sampel penelitian yaitu 153 orang.

Metode penelitian yang digunakan adalah survai analitik dengan desain cross sectional study. Pemilihan sampel dilakukan dengan cara non random yaitu total sampling. Instrumen penelitian yang digunakan adalah kuesioner. Data didapatkan secara langsung dari responden melalui kuesioner. Data dianalisis dengan secara komputerisasi. Analisis data meliputi analisis univariat dan bivariat. Analisis univariat dilakukan terhadap tiap variabel untuk menghasilkan distribusi frekuensi dari masing-masing variabel tersebut. Analisis bivariat yang digunakan adalah uji chi-square dengan derajat kemaknaan 0,05. Bila nilai $p \leq \alpha(0,05)$ berarti hasil perhitungan statistik bermakna (signifikan).

Hasil

Tabel 1. Distribusi frekuensi sindrom pramenstruasi pada siswi SMA

\begin{tabular}{lcc}
\hline \multicolumn{1}{c}{ Sindrom } \\
Pramenstruasi & $\mathbf{n}$ & \% \\
\hline Ya & 150 & 98 \\
Tidak & 3 & 2 \\
\hline Jumlah & $\mathbf{1 5 3}$ & $\mathbf{1 0 0}$ \\
\hline
\end{tabular}

Berdasarkan Tabel 1 dapat dilihat bahwa sebagian besar responden yaitu sebanyak 150 orang (98\%) mengalami sindrom pramenstruasisedangkan yang tidak mengalami sindrom pramenstruasi adalah sebanyak 3 orang (2\%).

Tabel 2. Distribusi frekuensi gejala sindrom pramenstruasi yang dialami oleh siswi SMA

\begin{tabular}{ccc}
\hline $\begin{array}{c}\text { Gejala Sindrom } \\
\text { Pramenstruasi }\end{array}$ & $\mathbf{N}$ & $\%$ \\
\hline Gejala Fisik (+) & 2 & 1,3 \\
Gejala Psikis (-) & 18 & 11,7 \\
$\begin{array}{l}\text { Gejala Fisik dan } \\
\text { Gejala Psikis (+) } \\
\text { Gejala Fisik dan } \\
\text { Gejala Psikis (-) }\end{array}$ & 130 & 84,9 \\
\hline Jumlah & 3 & 2 \\
\hline
\end{tabular}


Pada Tabel 2 terlihat sebagian besar responden $(84,9 \%)$ mengalami gejala fisik dan gejala psikis dan sebagian kecilresponden $(1,3 \%)$ mengalami gejala fisik saja.

Tabel 3. Distribusi frekuensi derajat gangguan aktivitas belajar akibat sindrom pramenstruasi

\begin{tabular}{llcc}
\hline \multicolumn{1}{c}{ Derajat Gangguan } & $\mathbf{n}$ & $\%$ \\
\hline 1. & $\begin{array}{l}\text { Masih dapat mengikuti aktivitas } \\
\text { belajar di sekolah atau di tempat } \\
\text { kursus tapi tidak mampu } \\
\text { berkonsentrasi dengan baik ( Ringan ) }\end{array}$ & 108 & 72 \\
2. $\begin{array}{l}\text { Tidak dapat mengikuti aktivitas belajar } \\
\text { di sekolah atau di tempat kursus } \\
\text { namun masih mampu belajar di } \\
\text { rumah ( Sedang ) }\end{array}$ & 23 & 15,3 \\
3. $\begin{array}{l}\text { Tidak dapat mengikuti aktivitas belajar } \\
\text { baik di sekolah, di tempat kursus } \\
\text { ataupun di rumah } \\
\text { ( Berat ) }\end{array}$ & & \\
4. $\begin{array}{l}\text { Hilangnya minat untuk beraktivitas } \\
\text { ( Sangat Berat ) }\end{array}$ & 5 & 3,3 \\
\hline \multicolumn{1}{c}{ Jumlah } & 14 & 9,3 \\
\hline
\end{tabular}

Pada Tabel 3 terlihat bahwa lebih dari separuh responden $(72 \%)$ mengalami gangguan belajar yang ringan yaitu masih dapat mengikuti aktivitas belajar di sekolah atau di tempat kursus tapi tidak mampu berkonsentrasi dengan baik.

Tabel 4. Hubungan antara gejala SPM (sindrom pramenstruasi) dengan derajat gangguan aktivitas belajar siswi SMA

\begin{tabular}{|c|c|c|c|c|c|c|}
\hline \multirow{2}{*}{$\begin{array}{l}\text { Gejala } \\
\text { SPM }\end{array}$} & \multicolumn{4}{|c|}{ Derajat Gangguan Aktivitas Belajar } & \multirow[t]{2}{*}{ Total } & \multirow[b]{2}{*}{$\mathbf{p}$} \\
\hline & Ringan & Sedang & Berat & $\begin{array}{l}\text { Sangat } \\
\text { berat }\end{array}$ & & \\
\hline Gejala & 2 & - & - & - & 2 & \\
\hline \multicolumn{7}{|l|}{ Fisik } \\
\hline Gejala & 8 & 8 & - & 2 & 18 & \\
\hline \multicolumn{7}{|l|}{ Psikis } \\
\hline Gejala & 98 & 15 & 5 & 12 & 130 & \\
\hline \multicolumn{7}{|l|}{ Fisik } \\
\hline \multicolumn{7}{|l|}{ dan } \\
\hline Psikis & & & & & & 0,022 \\
\hline
\end{tabular}

Berdasarkan Tabel 4 dapat dilihat proporsi responden yang mengalami gangguan aktivitas belajar ringan lebih banyak terjadi pada responden yang mengalami gejala fisik dan psikis. Hasil uji statistik dengan menggunakan chi-square, diperoleh nilai $p=$ $0,022(p<0,05)$. Berdasarkan hasil tersebut, dapat disimpulkanbahwa terdapat hubungan yang bermakna antara gejala sindrom pramenstruasi dengan derajat gangguan aktivitas belajar siswi SMA.

\section{PEMBAHASAN}

Hasil penelitian terhadap 153 siswi kelas XI SMAN 1 Payakumbuh, didapatkan sebanyak 150 orang (98\%) responden mengalami sindrom pramenstruasi. Hal ini sejalan dengan kepustakaan yang menyebutkan bahwa sekitar sepertiga wanita yang dalam usia reproduktif mengalami sindrom pramenstruasi. $^{2}$ Sebanyak 14 sampai $98 \%$ remaja putri memiliki gejala sindrom pramenstruasi ini. ${ }^{5}$

Gejala fisik dan psikis sindrom pramenstruasi dialami oleh 30 orang $(84,9 \%)$ responden. Responden yang mengalami gejala fisik atau gejala psikis saja yaitu $(1,3 \%)$ dan $(11,7 \%)$. Hal ini sejalan dengan kepustakaan bahwa keluhan atau gejala yang sering ditemukan adalah gejala fisik dan gejala psikis. Gejala fisik seperti nyeri kepala, nyeri dan pembengkakan payudara, perubahan pola defekasi, gangguan koordinasi dan edema pada tungkai. ${ }^{8}$

Gejala fisik yang terbanyak dialami responden adalah nyeri otot atau sendi yaitu sebanyak 69 orang (45,09\%). Pembengkakan pada kaki atau tangan dan berat badan bertambah jarang dikeluhkan yaitu $(3,26 \%)$ dan (1,96\%). Mudah tersinggung $(65,53 \%)$, marah tidak beralasan $(54,90 \%)$,mudah lelah atau letih $(50,32 \%)$, dan kurang minat untuk melakukan aktivitas $(45,75 \%)$ adalah gejala-gejala psikis yang terbanyak dikeluhkan oleh responden.

Pada penelitian ini diperoleh sebanyak 108 orang $(72 \%)$ responden mengalami gangguan belajar ringan yaitu masih dapat mengikuti aktivitas belajar di sekolah atau di tempat kursus tapi tidak mampu berkonsentrasi dengan baik. Sedangkan gangguan belajar yang sangat berat yaitu berupa hilangnya 
minat untuk beraktivitas hanya dialami oleh 14 orang responden $(9,3 \%)$. Hal ini sejalan dengan penelitian yang dilakukan Vistary, dimana diperoleh lebih dari separuh responden $(55,6 \%)$ mengalami gangguan kegiatan belajar yang ringan. ${ }^{7}$ Menurut kepustakaan bahwa gejala sindrom pramenstruasi telah menyebabkan terganggunya aktivitas sehari-hari wanita, seperti terganggunya komunikasi interpersonal dan aktivitas pekerjaan tak terkecuali aktivitas belajar. ${ }^{4}$ Berdasarkan data yang didapatkan di lapangan keluhan perut kembung $(38,6 \%)$ dan kurang konsentrasi $(20 \%)$ yang menjadi penyebab utama terganggunyaaktivitas belajar responden.

Proporsi responden yang mengalami gangguan aktivitas belajar ringan lebih banyak terjadi pada responden yang mengalami gejala fisik dan psikis sekaligus yaitu sebesar $75,4 \%$. Hasil uji statistik dengan menggunakan chi-square, diperoleh nilai $p=$ $0,022(p<0,05)$. Berdasarkan hasil tersebut, dapat disimpulkan bahwa terdapat hubungan yang bermakna antara gejala sindrom pramenstruasi dengan derajat gangguan aktivitas belajar siswi SMA. Hal ini sejalan dengan penelitian tentang sindrom pramenstruasi yang dilakukan terhadap mahasiswi Fakultas Kedokteran Universitas Andalas angkatan 2000/2001, didapatkan bahwa $80,89 \%$ sampel penelitian menderita sindrom ini dan $61,6 \%$ diantaranya mengalami gangguan belajar. ${ }^{7}$ Sindrom pramenstruasi yang diperlihatkan sebagai suatu penampilan siklik dari satu atau lebih gejala yang terjadi sesaat sebelum proses menstruasi telah mempengaruhi aktivitas seorang wanita. ${ }^{4}$

\section{SIMPULAN}

Terdapat hubungan yang bermakna antara gejala sindrom pramenstruasi dengan derajat gangguan aktivitas belajar.

\section{DAFTAR PUSTAKA}

1. Surya H. Percaya diri itu penting. Jakarta: PT Elex Media Komputindo. 2007.hlm.86.

2. Berhman E, Richard. Nelson textbook and pediatri. Minessota: Saunders.1992.

3. Kaplan, Harold I, Sadock. Sinopsis psikiatri. Jakarta: Bina Rupa. 2008.hlm.307-8.

4. Speroff, Leon, Marc AF. Clinical gynecologi endocrinology and infertility. Philadelpia: Lippincott Williams \& Walkins. 2005.

5. Derman. Premenstrual syndrome and premenstrual dysphoric disorders in adolesences. 2008 (diunduh 30 Januari 2011). Tersedia dari: URL: HYPERLINK http://www.medsape.om/ viewartile/551199

6. Essel EK. PMS Is It Real?. 2011 (diunduh 27 Januari 2012). Tersedia dari: URL: HYPERLINK http://www2.gsu.edu/

7. Vistary $O$. Pengaruh sindrom pramenstruasi terhadap kegiatan belajar mahasiswi fakultas kedokteran Universitas Andalas Padang tahun ajaran 2000/2001 (skripsi). Padang: Fakultas Kedokteran Universitas Andalas; 2001

8. Haker NF, Moore JF. Essensial obstetri dan ginekologi. Jakarta: Hipokrates. 2001.hlm.366-8 